




\title{
Copper thiosemicarbazones: Antiproliferative action against C6 glioma cells
}

\author{
Qiang Fu', Zhi-Yu Gao', Jie Zhang², Han-Yu Sun', Chao Liu' ${ }^{1}$ and Jin-Hong Ren' \\ ${ }^{1}$ Department of Neurosurgery, Liaocheng People's Hospital, Liaocheng, Shandong 252000, China; ${ }^{2}$ Department of \\ Pathology, Liaocheng People's Hospital, Liaocheng, Shandong 252000, China.
}

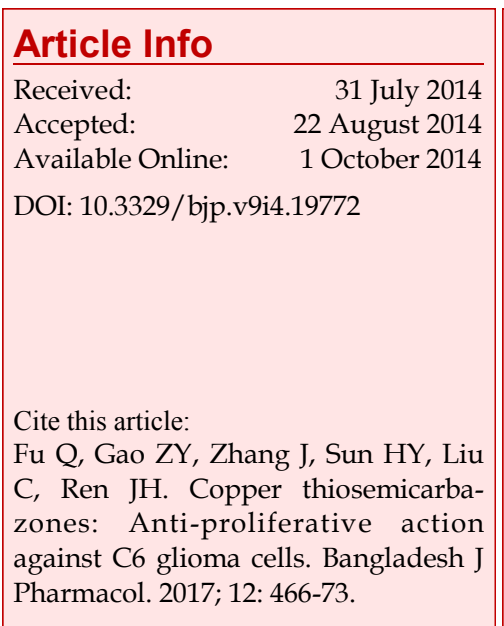

\section{Abstract}

2(E)-2-[1-(4-pyridinyl)ethylidene]hydrazinecarbothioammidehydrochloride (1) and two of its copper complexes were synthesized and structurally characterized. $\mathrm{Cu}(\mathrm{I})$ polymeric complex $\{[\mathrm{Cu}(\mathrm{SCN})(3-\mathrm{Acpy}) 2]\} \mathrm{n}(2)$ was synthesized by in situ mixing of $\mathrm{Cu}\left(\mathrm{BF}_{4}\right)_{2} .6 \mathrm{H}_{2} \mathrm{O}, 4$-acetylpyridine (4-Acpy) and semicarbazide whereas a dinuclear $\mathrm{Cu}$ (II) complex (3) was obtained from the reaction of $\mathrm{Cu}\left(\mathrm{BF}_{4}\right)_{2} .6 \mathrm{H}_{2} \mathrm{O}$, 4-acetylpyridine and ammonium thiocyanate. Magnetic measurements were performed for the dinuclear complex. All the thiosemicarbazones were cytotoxic against malignant RT2 glioblastoma cells (expressing p53 protein) with $\mathrm{IC}_{50}$ values in the 5.1-13.2 $\mu \mathrm{M}$ range, and against malignant T98 glioblastoma cells (expressing mutant p53 protein) with $\mathrm{IC}_{50}$ values in the $4.5-31 \mu \mathrm{M}$ range. Coordination to copper strongly increased the cytotoxic potential in complexes 2 and 3, when compared to that of free ligand and were found to be more potent than cisplatin. All the test compounds (1-3) were able to induce cell death by apoptosis.

\section{Introduction}

Gliomas are the most common primary tumors of central nervous system in humans (Levin et al., 1993) and they are classified into 4 clinical grades out of which the glioblastoma multiformis the most aggressive one (Dai and Holland, 2001). Most human gliomas generally affect either signal transduction pathways activated by the receptor tyrosine kinases or cell cycle arrest pathways activated by the receptor tyrosinases, such as CDK 4, CDK 6, cyclin D1, MDM2, p16, p14, RB and p53. (N)-heterocyclic thiosemicarbazones derived from 2-formyl, 2-acetyl, and 2-benzoylpyridine have been extensively investigated, as well as the effects of metal coordination in their mechanism of action (Liberta and West, 1992; West et al., 1991). Complexes of d-metals with the condensation products of 3acetylpyridine (3-Acpy) with hydrazines, hydrazides and thiosemicarbazide as ligands have reported (Cobeljic et al., 2013). There are few papers that report complexes of derivatives of 3-Acpy with semicarbazide, semioxamazide and thiosemicarbazide (Khanpour et al., 2009; Mena et al., 2008) in which the 3-Acpy derivative is coordinated as a monodentate via carbonyl oxygen or as a monodentate via pyridine nitrogen. The current chemotherapeutic treatments are thus often ineffective due to the intrinsic chemoresistance of these tumors (Hosli et al., 1996). The identification of novel therapeutic agents able to inhibit the growth of these tumors is therefore essential to improve the prognosis of glioma patients. On these grounds, we decided to carry out 2(E)-2-[1-(4-pyridinyl)ethylidene]hydrazine carbothioammide hydrochloride (1) and its copper complexes (2 and 3) preparation and their cytotoxic activity against malignant glioblastoma cells.

\section{Materials and Methods}

All the reagent grade chemicals and solvents utilized 
for the synthesis of compounds 1-3 were obtained from commercial suppliers and used without further purification. The elemental analyses $(\mathrm{C}, \mathrm{H}, \mathrm{N}, \mathrm{S})$ were performed by the standard micromethods using the ELEMENTAR Vario ELIII C,H,N analyzer. IR spectra were recorded on Perkin-Elmer FT-IR 1725X spectrophotometer by the $\mathrm{KBr}$ technique in the region 4000-400 $\mathrm{cm}^{-1}$. Abbreviations used for IR spectra: vs, very strong; $\mathrm{s}$, strong; $\mathrm{m}$, medium; $\mathrm{w}$, weak. NMR spectra were obtained at room temperature with a Bruker DRX-400 Avance $(400 \mathrm{MHz})$ spectrometer using deuterated dimethylsulfoxide (DMSO- $\mathrm{d}_{6}$ ) as the solvent and tetramethylsilane (TMS) as internal reference. Splitting patterns are designated as follows: s, singlet; $d$, doublet; $\mathrm{dd}$, doublet of doublets. The electronic spectra were obtained in DMSO solution on a GBC UV-Vis Cintra 40 spectrophotometer and complex in a solution at $7 \times 10^{-4}$ $\mathrm{mol} / \mathrm{dm}^{3}$. The temperature dependence of magnetic susceptibility was measured on the powder sample by employing a commercial Quantum Design MPMS-XL-5 SQUID magnetometer, from 2 to $300 \mathrm{~K}$, and in a 5000 Oe magnetic field.

\section{Cell lines and culture conditions}

Wild-type malignant, RT2 and mutant p53 type, T98 glioblastoma cells were obtained from American Type Culture Collection (ATCC; Rockville, MD) and maintained in a Dulbecco's Modified Eagle's Medium (DMEM-Gibco)(Gaithersburg, MD,USA), supplemented with $10 \%$ fetal bovine serum and antibiotics $(50 \mathrm{U} / \mathrm{mL}$ penicillin/50 $\mu \mathrm{M}$ streptomycin), in a water jacketed incubator with humidified atmosphere of $5 \% \mathrm{CO}_{2} / 95 \%$ air at $37^{\circ} \mathrm{C}$. For all the experiments, cells were seeded at appropriate concentrations to ensure exponential growth. All the other chemicals and solvents used for biological experiments were purchased from Sigma (St. Louis, MO, USA).

\section{Cytotoxic activity}

To determine the cytotoxic potentials of synthesized compounds, 3-(4,5-dimethiol-2-thioazo-lyl)-2,5diphenyl tetrazoliumbromide (MTT) colorimetric assay (Graminha et al., 2008) was conducted. Briefly, logarithmic phase glioblastoma cells were treated with increasing concentrations of cisplatin (positive control) and test compounds $\left(1 \times 10^{-2} \mathrm{M}\right.$ to $\left.1 \times 10^{-12} \mathrm{M}\right)$. Drugs were previously dissolved in dimethylsulfoxide (DMSO) and the final concentrations were adjusted using DMEM in such a manner that final DMSO concentration was lower than $0.5 \%$. Following 48 hours treatment, MTT reagent was added to each well and kept for 4 hours incubation at $37^{\circ} \mathrm{C}$. DMSO was added to each well to dissolve formazan crystals and absorbance was measured at $560 \mathrm{~nm}$. Tests using DMSO $(0.5 \%$ in DMEM) as negative control were carried out in parallel.

\section{Morphological analysis of tumor cells}

For phase contrast microscopy, representative fields of cells were photographed using a TS100 (Nikon) microscope. Cells stained with DAPI were visualized using suspensions of treated or control cells placed in tissue culture dishes. Cells were fixed with methanol, rinsed with PBS and methanol, stained with DAPI in methanol, and observed using Nikon fluorescence microscopy under UV illumination.

\section{Direct hemolysis assay}

The hemolytic activity of the studied compounds was evaluated. Human blood, collected in tubes containing EDTA, was centrifuged at $700 \mathrm{x} \mathrm{g}$ for $10 \mathrm{~min}$. The pellet was washed three times with cold PBS $\mathrm{pH} 7.4$ by centrifugation, and resuspended in the same buffer. The release of hemoglobin was used to quantify the membrane-damaging properties of the compounds. As $100 \%$ and $0 \%$ values we used Triton X-100 and phosphate-buffer treated erythrocytes, respectively. Erythrocytes were incubated with increasing concentrations of the compounds in the $10^{-3}-10^{-8} \mathrm{M}$ range for 1 hour at $37^{\circ} \mathrm{C}$ in a shaker water bath. The release of hemoglobin was determined after centrifugation by photometric analysis at $540 \mathrm{~nm}$. Complete hemolysis was achieved using Triton X-100 yielding the $100 \%$ control value. Less than $10 \%$ hemolysis was regarded as non-toxic effect level in our experiments. The experiments were repeated twice and were run in triplicates.

\section{Statistical analysis}

Data were reported as mean $\pm S D$, expressed as percentage of cell viability relative to the untreated control. All tests were performed in triplicates with full agreement between the results. The statistical significance was assessed using Student's t-test $(\mathrm{p}<0.05)$.

\section{Results}

Ligand 1 was synthesized by the condensation reaction starting from 4-Acpy and thiosemicarbazide in a 1:1 M ratio in aqueous solution (Scheme 1). 4-Acetylpyridine (1 mmol, $0.11 \mathrm{~mL}$ ) was added to a solution of thiosemicarbazide hydrochloride $(1 \mathrm{mmol}, 91 \mathrm{mg})$ in water $(30 \mathrm{~mL})$ followed by a few drops of con. $\mathrm{HCl}$ and the mixture were refluxed for 4 hours and the resulting yellow color solution were filtered, evaporated and dried under vacuum. Yield: (150 mg, 70\%), m.p. 205-210 ${ }^{\circ} \mathrm{C}$. Anal. Calc. for $\mathrm{C}_{8} \mathrm{H}_{11} \mathrm{ClN}_{4} \mathrm{~S}$ : C,49.46; H, 5.19; N, 28.84; S, 16.51. Found: C, 49.37; H, 5.10; N, 28.76; S, $16.43 \%$. Selected IR frequencies $\left(\mathrm{KBr} ; \mathrm{v} / \mathrm{cm}^{-1}\right): 3258.2$ s,2358.5 w, $1640.3 \mathrm{~m}, 1499$ vs, 1475.3 vs, $1312.6 \mathrm{~m}, 1264.2$ m, 1088.4 s, $1019.7 \mathrm{w}, 847.1 \mathrm{w}, 702 \mathrm{~s}, 620.2 \mathrm{w} .{ }^{1} \mathrm{H}$ NMR (400 MHz; DMSO-d 6 ; Me $4 \mathrm{Si}) \delta: 10.3(\mathrm{~N} 3 \mathrm{H}, \mathrm{s}), 9.1(\mathrm{C} 1 \mathrm{H}$, d), $8.52(\mathrm{C} 5 \mathrm{H}, \mathrm{dd}), 8.3,8.0(\mathrm{~N} 4 \mathrm{H} 2, \mathrm{~d}), 8.3(\mathrm{C} 3 \mathrm{H}, \mathrm{dd}), 7.35$ $(\mathrm{C} 4 \mathrm{H}, \mathrm{dd}), 2.32(\mathrm{C} 8 \mathrm{H} 3, \mathrm{~s}) .{ }^{13} \mathrm{C}$ NMR $(400 \mathrm{MHz}, \mathrm{DMSO}-$ 
$\left.\mathrm{d}_{6} ; \mathrm{Me}_{4} \mathrm{Si}\right)$ d: $177.08,148.7,147.0,144.52,132.89,131.0$, 121.3, 13.70 .

To a solution containing thiosemicarbazide hydrochloride $(1 \mathrm{mmol}, 91 \mathrm{mg})$ in ethanol $(50 \mathrm{~mL})$ was added 4-acetylpyridine $(1 \mathrm{mmol}, 0.11 \mathrm{~mL})$ and $\mathrm{Cu}\left(\mathrm{BF}_{4}\right)$ ${ }_{2} .6 \mathrm{H}_{2} \mathrm{O}(0.5 \mathrm{mmol}, 172.5 \mathrm{mg})$ dissolved in $10 \mathrm{~mL}$ of ethanol. The mixture was refluxed for 6 hours and the resulted yellow-green solution was filtered, evaporated and dried under vacuum. Yield: $70 \mathrm{mg}, \sim 20 \%$, m.p. 262$265^{\circ} \mathrm{C}$. Anal. Calc. for $\mathrm{C}_{15} \mathrm{H}_{14} \mathrm{CuN}_{3} \mathrm{O}_{2} \mathrm{~S}$ : C, 49.57; $\mathrm{H}, 3.87$; N, 11.56; S, 8.80. Found: C, 49.40; H, 4.0; N, 11.77; S, $9.0 \%$. Selected IR frequencies $\left(\mathrm{KBr} ; \mathrm{v} / \mathrm{cm}^{-1}\right): 3354.2 \mathrm{w}$, $3050 \mathrm{w}, 2873.5 \mathrm{w}, 2085.4 \mathrm{~s}, 1688.3 \mathrm{vs}, 1593.6 \mathrm{~m}, 1423.6 \mathrm{~m}$, $1277.8 \mathrm{~s}, 1196.6 \mathrm{w}, 1030.5 \mathrm{~m}, 995.7 \mathrm{w}, 804.1 \mathrm{~m}, 702.6 \mathrm{~m}$, $637.3 \mathrm{w}, 601.2 \mathrm{w}$.

To a solution containing $\mathrm{NH}_{4} \mathrm{SCN}(1 \mathrm{mmol}, 76 \mathrm{mg})$ and 4-acetylpyridine $(1 \mathrm{mmol}, 0.11 \mathrm{~mL})$ in ethanol $(50 \mathrm{~mL})$ was added $\mathrm{Cu}\left(\mathrm{BF}_{4}\right)_{2} \cdot 6 \mathrm{H}_{2} \mathrm{O} \quad(0.5 \mathrm{mmol}, 172.5 \mathrm{mg})$ dissolved in $10 \mathrm{~mL}$ of ethanol. The mixture was refluxed for 6 hours and the resulted green color solution was filtered, evaporated and dried under vacuum. (200 mg, $\sim 25 \%)$. m.p. $194-198^{\circ} \mathrm{C}$. Anal. Calc. for $\mathrm{C}_{32} \mathrm{H}_{28} \mathrm{Cu}_{2} \mathrm{~N}_{8} \mathrm{O}_{4} \mathrm{~S}_{4}: \mathrm{C}, 45.53 ; \mathrm{H}, 3.33 ; \mathrm{N}, 13.23 ; \mathrm{S}, 15.20$. Found: C, 45.88; H, 3.40; N, 13.25; S, 15.0\%. Selected IR frequencies $\left(\mathrm{KBr} ; \mathrm{v} / \mathrm{cm}^{-1}\right)$ : $3097.1 \mathrm{w}, 3045.2 \mathrm{w}, 2912.5 \mathrm{w}$, 2103.2 vs, 2070.5 vs, 1690.3 vs, $1595.2 \mathrm{~s}, 1473.5 \mathrm{w}, 1431.7$ $\mathrm{m}, 1374.3 \mathrm{~m}, 1327.1 \mathrm{w}, 1274.2 \mathrm{~s}, 1197.7 \mathrm{w}, 1048.4 \mathrm{w}$, $960.9 \mathrm{w}, 821.7 \mathrm{w}, 687.5 \mathrm{~m}, 589.7 \mathrm{w}$. UV-Vis, $\lambda_{\max }(\mathrm{nm})$ $\left(\varepsilon_{\max },\left(\mathrm{dm}^{3} \mathrm{~mol}^{-1} \mathrm{~cm}^{-1}\right)\right)(\mathrm{DMSO}): 825(1145)$.

The infrared spectral data showed that both in dimeric and polymeric copper complexes, the band responsible for $\mathrm{C}=\mathrm{N}$ band at $1640 \mathrm{~cm}^{-1}$ was disappeared and a new band for $\mathrm{C}=\mathrm{O}$ group was appeared at $1688 \mathrm{~cm}^{-1}$, indicating the coordination of 4-acetylpyridine with the copper ion. The other important feature of the spectra is the presence of $\mathrm{v}(\mathrm{CN})$ bands of coordinated thiocyanate ion. In the dimer there observed, two strong bands, one at $2070 \mathrm{~cm}^{-1}$, and the other at $2103 \mathrm{~cm}^{-1}$. The first band corresponds to monodentately coordinated thiocyanate via the nitrogen atom (Fisher et al., 2003; Freshney et al., 2000), and the other to the bridging ligand. On the other hand, in the polymeric complex, there is only one thiocyanate band at $2085 \mathrm{~cm}^{-1}$ corresponding to the bridging ligand. In the UV-Vis spectrum of the $\mathrm{Cu}(\mathrm{II})$ complex 3 a broad band was observed at $825 \mathrm{~nm}$, corresponding to transition from e type orbitals to a1.
Due to instability of polymeric complex 2 in DMSO solution, UV-Vis and NMR spectra could not be recorded.

Magnetic data are shown in Figure 1, where temperature dependence of $\chi^{\mathrm{T}}$ and magnetic susceptibility $(\chi)$ per mol of $\mathrm{Cu}$ (II) dimer are presented. It can be seen that at room temperature $\chi^{\mathrm{T}}$ product is $0.80 \mathrm{emu} \mathrm{K}$ / mol. This value is higher than $0.73 \mathrm{emu} \mathrm{K} / \mathrm{mol}$ expected for two non-interacting $\mathrm{Cu}^{2+}$ ions $(\mathrm{S}=1 / 2 ; \mathrm{g}=$ 2) suggesting $g$-factor higher than 2 . Upon cooling $\chi^{T}$ value increases and shows broad maximum around 50 $\mathrm{K}(0.8 \mathrm{emu} \mathrm{K} / \mathrm{mol})$ indicating the presence of dominant ferromagnetic interaction. Upon further cooling this product decreases sharply to $0.7 \mathrm{emu} \mathrm{K} / \mathrm{mol}$ at $2 \mathrm{~K}$. This decrease may be due to the intermolecular antiferromagnetic exchange interactions and/or zerofield splitting of $S=1$ ground state. The data were corrected for the contributions of the sample holder and for the diamagnetism of the sample estimated from Pascal's constants.

In order to evaluate the exchange coupling constants, Eq. (1) were employed (Nakamoto, 1997):

$\chi_{M}=\mathrm{Ng}^{2} \mu^{2} \mathrm{~B} / \mathrm{k}_{\mathrm{B}} \mathrm{T}\left(\frac{2 \exp (\mathrm{D} / \mathrm{kBT})}{1+2 \exp \left(\frac{\mathrm{D}}{\mathrm{kBT}}\right)+\exp (-2 \mathrm{~J} / \mathrm{kBT})}\right)$ Eq $(1)$

In this equation $\mathrm{J}$ and $\mathrm{D}$ are magnetic interaction between two spins $S=1 / 2$ and axial zero-field splitting parameter for the $S=1$ state, respectively. In order to account for intermolecular interactions (zJ') mean field correction was added Eq. (2):

$$
x=\frac{\chi^{\mathrm{M}}}{1-\left(2 z J^{\prime} / \mathrm{Ng} 2 \mu 2 B\right) x^{\mathrm{M}}} \mathrm{Eq}(2)
$$

Least-squares fitting of all experimental data leads to the following parameters $\mathrm{J}=+54(2) \mathrm{cm}^{-1}, \mathrm{D}=1.54(5) \mathrm{cm}-$ ${ }^{1}, \mathrm{~J}^{\prime}=-1.02(5) \mathrm{cm}^{-1}, \mathrm{~g}=2.18(5)$ and $\mathrm{Na}=136 \times 10^{-6} \mathrm{emu} /$ mol. $\mathrm{R}$ value defined as $\mathrm{R}=\Sigma\left[\mathrm{X}_{\mathrm{obs}}-\mathrm{\chi}_{\text {calc }}\right]^{2} / \Sigma\left[\mathrm{X}_{\mathrm{obs}}\right]^{2}$ was found to be $4.72 \times 10^{-6}$. Positive J value confirms signifycant intra dimer ferromagnetic coupling. Similar magnetic behavior with strong ferromagnetic interaction (J $=50 \mathrm{~cm}^{-1}$ ) was reported for $\mathrm{Cu}$ (II) dimer bridged with two thiocyanate groups (Ma et al., 2006) as well as $\mathrm{Cu}$ (II) complexes with various ligands (Chi et al., 2011; Fondo et al., 2005; Paul et al., 2011). Negative zJ' value show interdimer antiferromagnetic interactions which

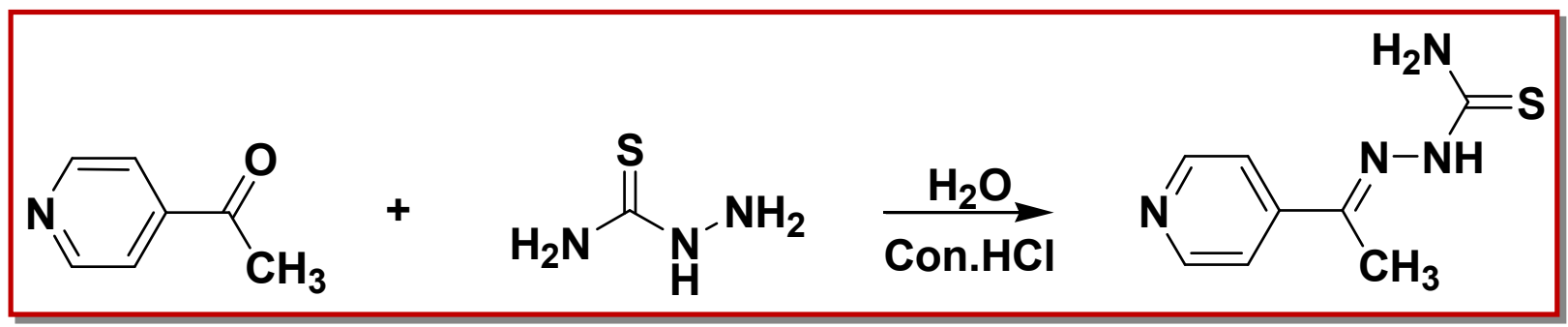




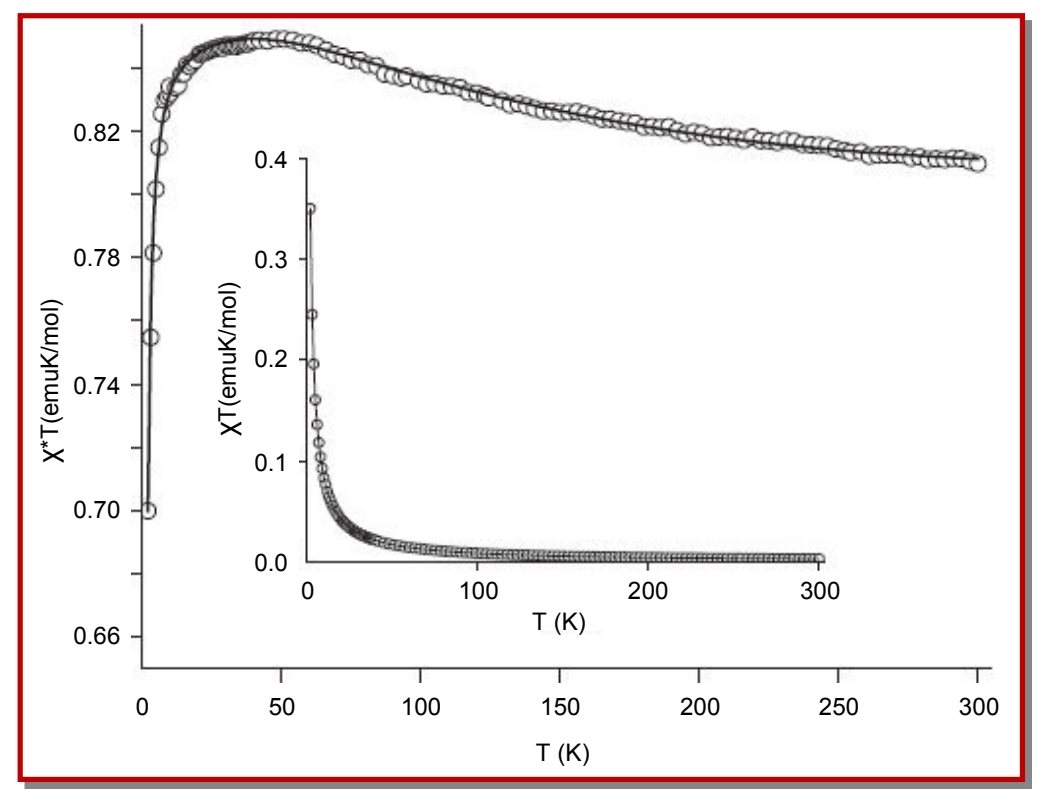

Figure 1: Temperature dependences of $\chi \mathrm{T}$ (open circles) and $\chi(\mathrm{T})$ (iset). Solid line is the best fit of the experimental data using Eqs. (1) and (2)

together with zero field splitting $\mathrm{D}$ cause sharp decrease of $\chi^{\mathrm{T}}$ below $20 \mathrm{~K}$.

Thiosemicarbazone and its copper complexes induce membrane changes characteristics of apoptosis. A wide range of phenotypic modifications were occurred in glioblastoma cells after exposure to the thiosemicarbazones and its copper complexes. Figure 2 shows control glioblastoma cells and cells treated complexes 2 and 3 . After treatment with thiosemicarbazone and its copper complexes, retraction of the cytoplasmatic expansions was noticed leading to round shaped cells, cell shrinkage and blebs formation. In addition, reduction in the cell counts was also observed after treatment. These morphological changes are associated with apoptosis.

Programmed cell death (apoptosis) induces DNA fragmentation through the activation of specific DNA endonucleases (Fondo et al., 2005). Activation of nucleases can be evidenced through the use of DNA staining with 4',6'-diamidino-2-phenylindole (DAPI), which detects fragmented and condensed DNA. No DNA fragmentation was observed in the untreated cells, but following exposure to the cells exhibited extensive DNA fragmentation as seen in Figure 3 for complexes 2 and 3.

The concentrations of the studied compounds (1-3) which kill $50 \%$ of RT2 and T98 glioblastoma cells (IC 50$)$ are listed in Table I and their corresponding concentration-effect curves are shown in Figure 4. The results show that both the thiosemicarbazone and its copper complexes were highly active against malignant glioblastoma. All the compounds were more active than the antitumor agent cisplatin, $\mathrm{IC}_{50}=19 \mu \mathrm{M}$ (RT2) and $\mathrm{IC}_{50}=4 \mu \mathrm{M}$ (T98). The activity decreases in following order: $2>3>1$. The compound 1 has lower potential when compared to complexes 2 and 3 due to the lack of coordination with metal ion. Among 2 and 3, polymeric copper complex shows more activity which is probably due to the increasing units of thiosemicarbazones attached and indicates clearly that thiosemicarbazone unit is the biological targets. Interestingly, it is worth noting that coordination to copper ion strongly increased the cytotoxic potential of the thiosemicarbazone. The $\mathrm{IC}_{50}$ of $\mathrm{Cu}\left(\mathrm{BF}_{4}\right)_{2} \cdot 6 \mathrm{H}_{2} \mathrm{O}$ against $\mathrm{RT} 2$ and T98 are found to be $>100$ and $>1000 \mu \mathrm{M}$, respectively which are too low than those of other compounds studied. Moreover, upon coordination to the thiosemicarbazone, copper lipophilicity probably increases. Since, $\mathrm{Cu}\left(\mathrm{BF}_{4}\right)_{2} \cdot 6 \mathrm{H}_{2} \mathrm{O}$ possess lower activity and complex 2 presented higher cytotoxic activity. The high cyto -toxic effect of 2 is probably due to the complex as an entity. Some reported cytotoxicity of metal complexes with acetylpyridine and acetylpyrazine-derived $\mathrm{N}$ heterocyclic thiosemicarbazones against the $41 \mathrm{M}$ (ovarian carcinoma), SK-BR-3 (mammary carcinoma) and SW480 (colon carcinoma) human cancer cell lines with $\mathrm{IC}_{50}$ values in the nanomolar range (Enari et al., 1998; Kowol et al., 2007). However, to the best of our knowledge the present work reports for the first time the cytotoxicity of copper complexes against brain tumor cells.

The release of hemoglobin was used to quantify the membrane damaging properties of the compounds. The hemolysis test evaluated the red blood cells (RBCs) membrane disruption potential of the studied compounds. This assay uses the RBC membrane as an endosomal membrane model (Arion et al., 2002). Under the assayed conditions, the hemolytic activity of $\mathrm{Cu}$ $\left(\mathrm{BF}_{4}\right)_{2} \cdot 6 \mathrm{H}_{2} \mathrm{O}$ and all studied compounds (1-3) was very 


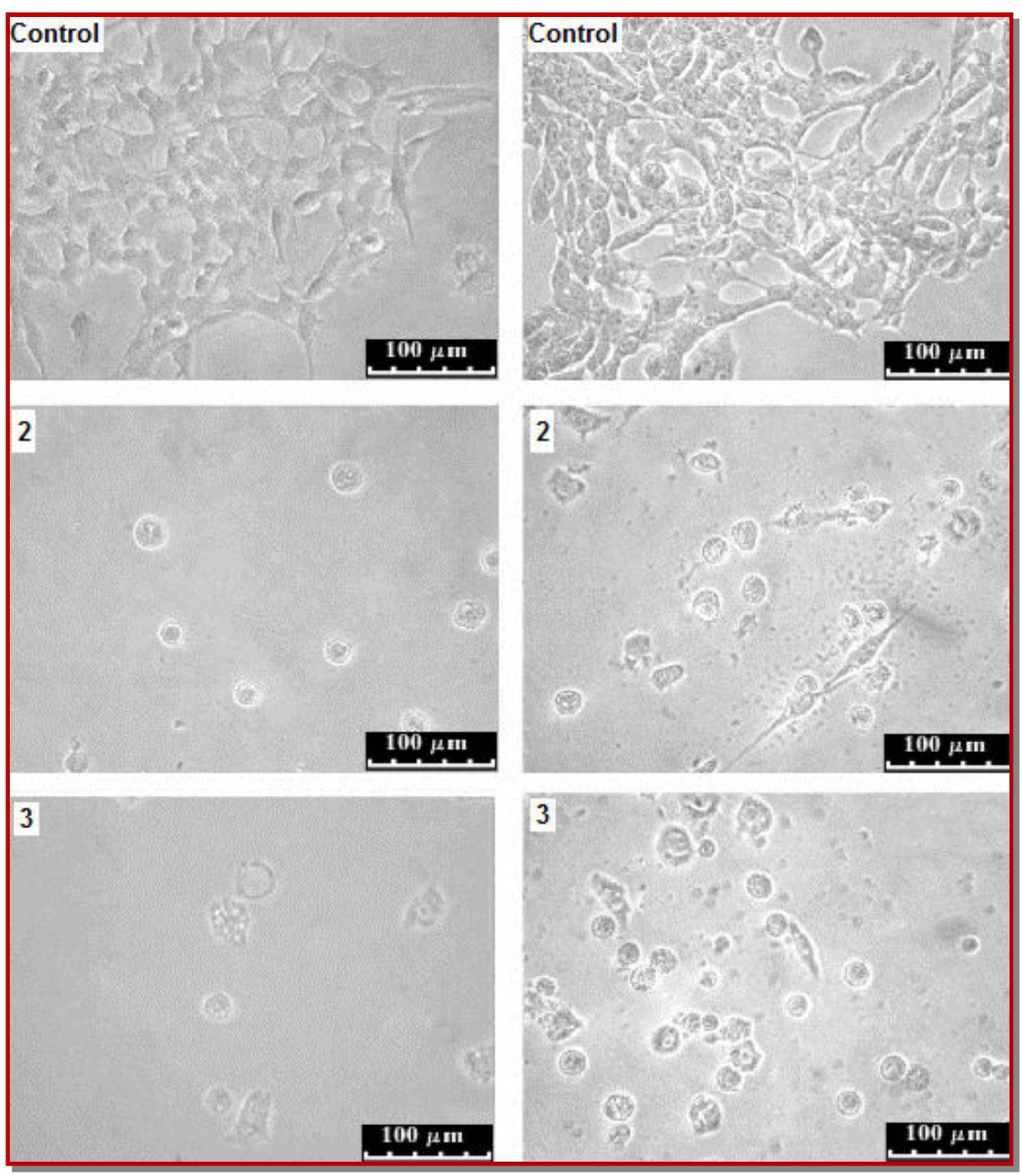

Figure 2: Cells treated with complexes $\left(10^{-4} \mathrm{M}\right)$ exhibit membrane changes characteristic of apoptosis. Control or treated RT2 (on the left column) and T98 (on the right column) cells were incubated in culture dishes. After $48 \mathrm{~h}$ treatment the dishes were observed under phase contrast and membrane morphology photographed. Characteristics of apoptosis are clearly visible and are indicated: Retraction of cell expansions, rounding cell, blebs. Magnification x 200

low at $\mathrm{pH} 7.4\left(\mathrm{IC}_{50}>10^{-3} \mathrm{M}\right)$ near that of the control sample, indicating no detectable disturbance of red blood cell membrane.

\section{Discussion}

It is well known that glioblastoma cells express wildtype p53 protein (Jones et al., 2003). In fact, apoptosis of these cells is triggered primarily bya p53 pathway, evidencing that RT2 cells have functional p53 protein. Previous characterization of p53 genotype and drug sensitivity of human cancer cell lines has revealed that cells with mutant or absent p53 are less sensitive than cells with wild-typep53 to the majority of clinically used anti-cancer agents, including DNA alkylating agents. Heterocyclic $N(4)$-substituted thiosemi-carbazones, $N$-(2)-pyridyl- $N$ '-arylthioureas, and 2-substituted pyridine $N$-oxides and their copper(II) complexes have been shown to be potent antineoplastic agents, and cytotoxicity has been demonstrated against the growth of a number of murine and human tumor cells (O'Connor et al., 1997, Miller et al., 1999). The 2acetylpyridine $N(4)$-substituted thiosemicarbazones have demonstrated significant activity in the $\mathrm{NCI}$ screens for non-small cell lung cancer, breast cancer, and prostate cancer and leukemias. The 2-formyl,2acetyl-, and 2-benzoylpyridine N(4)-substituted thiosemicarbazones and their copper complexes demonstrated potent cytotoxic activity against the growth of human MCK-7 breast effusion, lung A549, and lung MB -9812, bone osteosarcoma Saos-2, and clear cell Caki renal tumor.

Complexes 2 and 3 are found to be more active against both T98 (with mutant p53) cells and RT2 (presenting wild-type p53) cells when compared to that free ligand 1. Among these two complexes, complex 2 possess more activity against both cell lines. Therefore, it is clear that thiosemicarbazone coordination with the 

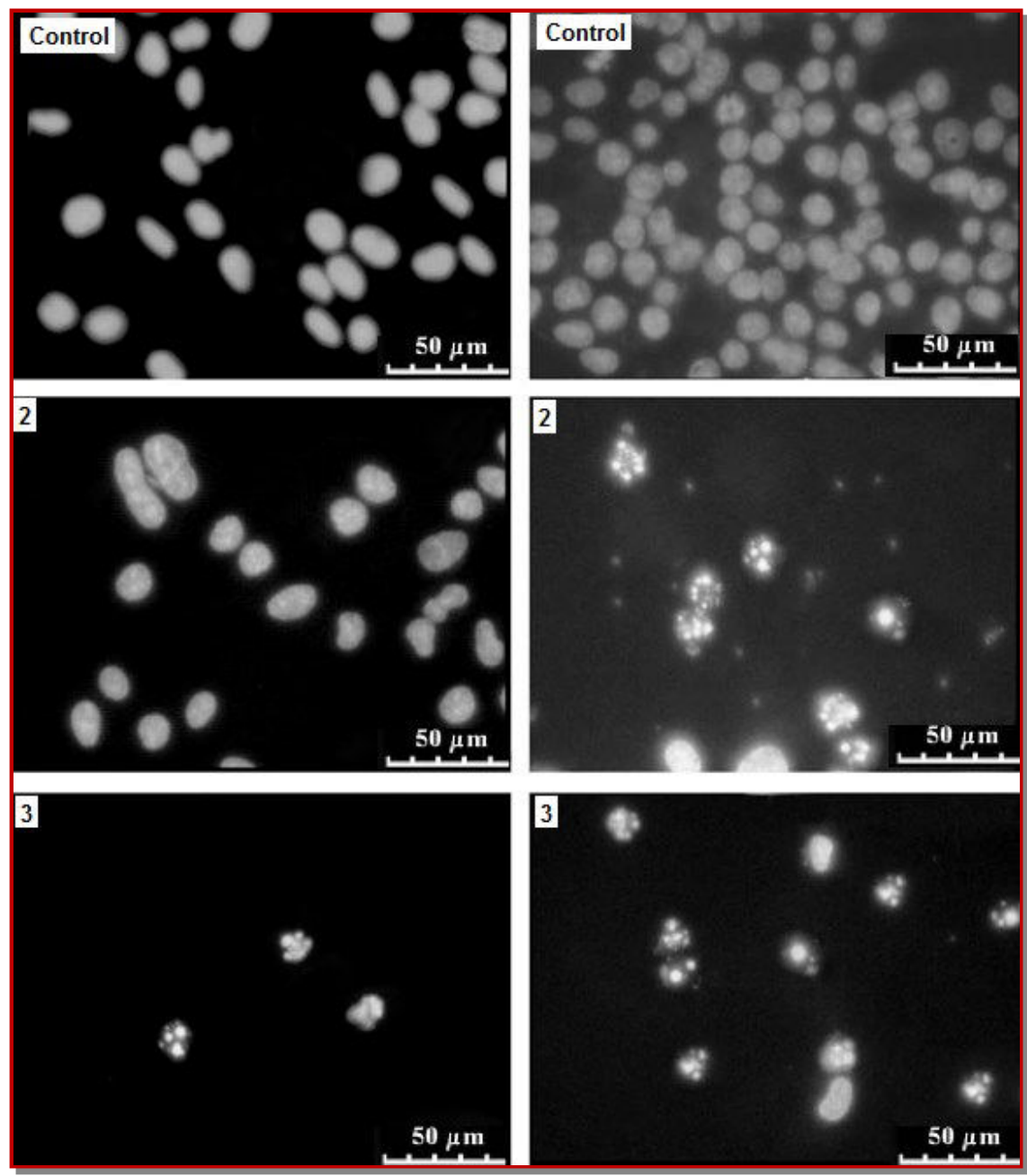

Figure 3: Cells treated with complexes exhibit nuclear changes characteristic of apoptosis. RT2 (on the left column) and T98 (on the right column) cells were treated with complexes $\left(10^{-4} \mathrm{M}\right)$ or diluent (Control). After 48 hours treatment, cells were fixed and stained with DAPI. It can be observed chromatin condensation, nuclear fragmentation and apoptotic bodies. Magnification x 400

copper ion is found to have more activity which can probably activate apoptotic cell death pathways by mechanisms that are both dependent and independent of p53. Hence the studied compounds can recruit more than one pathway to trigger cell death, therefore, enhancing their utility in anti-cancer therapy. The glioblastoma cells used in this work are resistant to starting material, $\mathrm{Cu}\left(\mathrm{BF}_{4}\right)_{2} \cdot 6 \mathrm{H}_{2} \mathrm{O}$. This further supports that coordination leads to the enhancement of cytotoxic effect of the thiosemicarbazone and of copper. This could be a strategy of broadening the spectrum of antitumor activity of both copper and thiosemicarbazone against brain tumors. Because approximately two-thirds of gliomas have defects in the p53 pathway, the ability of the studied compounds to affect cells regardless of their p53 status suggests that they have a good potential to be developed into novel drug candidates for the therapy of brain tumors. The low hemolytic activity of all studied compounds suggests that further investigations on their pharmacological behavior should be carried out.
In conclusion, we synthesized and characterized three compounds, thiosemicarbazone (1) and two of its copper complexes (2 and 3 ). The antitumor effects of all three synthesized compounds were tested against RT2 and T98 glioblastoma cells. The results obtained clearly demonstrated that these compounds can serve as the potential anti-tumor agent against brain tumor.

\section{References}

Arion VB, Jakupec MA, Galanski M, Unfried P, Keppler BK. Synthesis, structure, spectroscopic and in vitro antitumour studies of a novel gallium(III) complex with 2acetylpyridine (4)N-dimethylthiosemicarbazone. J Inorg Biochem. 2002; 91: 298-305.

Chi YH, Yu L, Shi JM, Zhang YQ, Hu TQ, Zhang GQ, Shi W, Cheng Р. п-п Stacking and ferromagnetic coupling mechanism on a binuclear $\mathrm{Cu}(\mathrm{II})$ complex. Dalton Trans. 2011; 40: 1453-62.

Cobeljic B, Pevec A, Turel I, Swart M, Mitic D, Milenkovic M, 


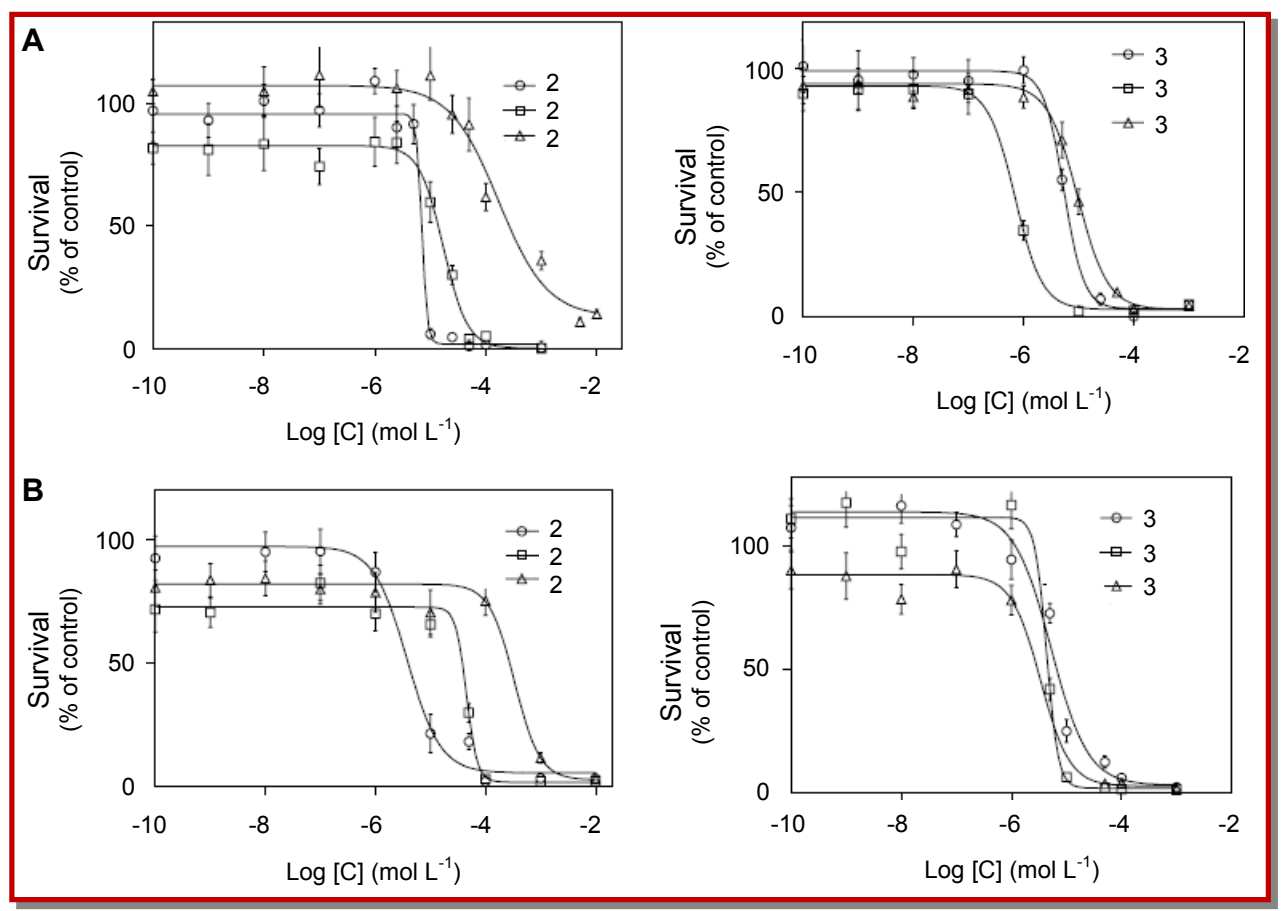

Figure 4: Concentration-effect curves for the complexes 1-3 obtained by MTT assay in RT2 (A) and T98 (B) gliobalstom cells

\begin{tabular}{|c|c|c|}
\hline \multicolumn{3}{|c|}{ Table I } \\
\hline \multicolumn{3}{|c|}{$\begin{array}{l}\text { Cytotoxic effect of thiosemicarbazones and its cop- } \\
\text { per complexes on glioblastoma cells }\end{array}$} \\
\hline Compound & $\mathrm{IC}_{50}$ values & $\mathrm{IC}_{50}$ values \\
\hline & RT2 & T98 \\
\hline 1 & $13.2 \pm 0.7$ & $31 \pm 1$ \\
\hline 2 & $0.8 \pm 0.03$ & $4.5 \pm 0.9$ \\
\hline 3 & $5.1 \pm 0.03$ & $5.9 \pm 0.3$ \\
\hline $\mathrm{Cu}\left(\mathrm{BF}_{4}\right)_{2} \cdot 6 \mathrm{H}_{2} \mathrm{O}$ & $>100$ & $>1000$ \\
\hline Cisplatin & $19 \pm 1$ & $4 \pm 3$ \\
\hline
\end{tabular}

Markovic I, Jovanovic M, Sladic D, Jeremic M, Andelkovic K. Synthesis, characterization, DFT calculations and biological activity of derivatives of 3-acetylpyridine and the zinc(II) complex with the condensation product of 3acetylpyridine and semicarbazide. Inorg Chim Acta. 2013; 404: 5-12.

Dai C, Holland EC. Glioma models. Biochim Biophys Acta. 2001; 1551: M19-M27.

Enari M, Sakahira H,Yokoyama H, Okawa K, Iwamatsu A, Nagata S. A caspase-activated Dnase that degrades DNA during apoptosis, and its inhibitor ICAD. Nature 1998; 391: 43-50.

Fisher D, Li Y, Ahlemeyer B, Krieglstein J, Kissel T. In vitro cytotoxicity testing of polycations: Influence of polymer structure on cell viability and hemolysis. Biomaterials 2003; 24: 1121-31.

Fondo M, Garcia-Deibe AM, Corbella M, Ruiz E, Tercero J, Sanmartin J, Bermejo MR. Unexpected ferromagnetic interaction in a new tetranuclear copper(II) complex: Synthesis, crystal structure, magnetic properties, and theoretical studies. Inorg Chem. 2005; 44: 5011-20.

Fondo M, Ocampo N, Garcia-Deibe AM, Corbella M, Bermejo MR, Sanmartin J. Ferromagnetism in dinuclear copper(II)phenolate complexes with exogenous O-donor bridges: A comparative study. Dalton Trans. 2005; 3785-94.

Freshney RI. Culture of animal cells: A manual of basic technique. 4th ed. Wiley Liss, 2000.

Graminha AE, Rodrigues C, Batista AA, Teixeira LR, Fagundes ES, Beraldo H. Ruthenium(II) complexes of 2-benzoylpyridine-derived thiosemicarbazones with cytotoxic activity against human tumor cell lines. Spectrochim Acta Part A: Mol Biomol Spectrosc. 2008; 69: 1073-76.

Hosli AP, Sappino N, De Tribolet, Dietrich PY. Malignant glioma: Should chemotherapy be overthrown by experimental treatments? Ann Oncol. 1996; 9: 589-600.

Jones RA, Cheung CY, Black FE, Zia JK, Stayton PS, Hoffman AS, Wilson MR. Poly(2-alkylacrylic acid) polymers deliver molecules to the cytosol by $\mathrm{pH}$-sensitive disruption of endosomal vesicles. Biochem J. 2003; 372: 65-75.

Khanpour M, Morsali A. Solid state crystal-to-crystal transformation from a monomeric structure to 1-D coordination polymers on anion exchange. Cryst Eng Comm. 2009; 11: 2585-87.

Kowol CR, Berger R, Eichinger R, Roller A, Jakupec MA, Schmidt PP, Arion VB, Keppler BK. Gallium(III) and iron (III) complexes of alpha-N-heterocyclic thiosemicarbazones: Synthesis, characterization, cytotoxicity, and interaction with ribonucleotide reductase. J Med Chem. 2007; 50: 125465 .

Levin VA, Gutin PH, Leibel S, Vita VTD, Hellman S, 
Rosenberg AS. Cancer: Principles and Practice of Oncology, Lippincott, Philadelphia, 1993, 1697-737.

Liberta AE, West DX. Antifungal and antitumor activity of heterocyclic thiosemicarbazones and their metal complexes: current status. Biometals 1992; 5: 121-26

Ma Y, Gao DZ, Zhang W, Yoshimura K, Liao DZ, Jiang ZH, Yan SP. A novel copper(II)-radical complex with ferromagnetic interaction: Synthesis, crystal structure and magnetic properties. Inorg Chim Acta. 2006; 359: 4655-59.

Mena A, Bastos B, da Silva JG, da Maia PIDS, Deflon VM, Batista AA, Ferreira AVM, Botion LM, Niquet E, Beraldo H. Oxovanadium (IV) and (V) complexes of acetylpyridinederived semicarbazones exhibit insulin like activity. Polyhedron 2008; 27: 1787-94.

Miller MC III, Stineman CN, Vance JR, West DX, Hall IH. Multiple mechanisms for cytotoxicity induced by copper(II) complexes of 2-acetylpyrazine-N-substituted thiosemicarbazones. J Appl Organometal Chem. 1999; 13: 9-19.
Nakamoto K. Infrared and Raman spectra of inorganic and coordination compounds. 5th ed. New York, John Wiley \& Sons Inc, 1997.

O’ Connor PM, Jackman J, Bae I,Myers TG, Fan S, Mutoh M, Scudiero DA, Monks A, Sausville EA, Weinstein JN, Friend S, Fornace AJ, Kohn KW. Characterization of the p53 tumor suppressor pathway in cell lines of the National Cancer Institute anti-cancer drug screen and correlations with the growth-inhibitory potency of 123 anti-cancer agents. Cancer Res. 1997; 57: 4285-300.

Paul S, Nanda PK, Mathoniere C, Hearns NGR, Clerac R, Ray D. Aqua bridge cleavage and metal ion extrusion by thiocyanate anions in a dicopper complex. Inorg Chim Acta. 2011; 370: 108-16.

West DX, Padhye S, Sonawane PB. Structural and physical correlation in the biological properties of transition metal Nheterocyclic thiosemicarbazones and S-alkyldithiocarbazate complexes. Struct Bond. 1991; 76: 1-50. 